\title{
GMR
}

\section{Population genetic analysis and conservation strategies for redtail shrimp Fenneropenaeus penicillatus using ten microsatellite markers}

\author{
Y.Y. Cao ${ }^{1,2}$, J.B. Shangguan ${ }^{1,2}$ and Z.B. Li ${ }^{1,2}$ \\ ${ }^{1}$ Fisheries College, Jimei University, Xiamen, China \\ ${ }^{2}$ Fujian Provincial Key Laboratory of Marine Fishery Resources and Eco-environment, \\ Xiamen, China \\ Corresponding author: Z.B. Li \\ E-mail: lizhongbao@jmu.edu.cn \\ Genet. Mol. Res. 16 (1): gmr16019068 \\ Received August 10, 2016 \\ Accepted December 5, 2016 \\ Published March 15, 2017 \\ DOI http://dx.doi.org/10.4238/gmr16019068 \\ Copyright (C) 2017 The Authors. This is an open-access article distributed under the terms of \\ the Creative Commons Attribution ShareAlike (CC BY-SA) 4.0 License.
}

\begin{abstract}
Fenneropenaeus penicillatus, which is on the Red List of Endangered Species for China, is an important shrimp species. However, there is not enough genetic information on $F$. penicillatus for conservation and management purposes. Ten microsatellite markers were used to analyze the genetic diversity, genetic differentiation, and population structure of $F$. penicillatus to provide scientific information for the conservation of the species. Low genetic diversity and moderate genetic differentiation were found among 12 putative populations [Beihai, Dongshan (DS), Hainan (HN), Lianjiang, Nanao (NA), Ningde (ND), Putian, Quanzhou (QZ), Xiamen (XM), Shenzhen, Zhanjiang, and Zhangpu] along the southeast coast of China. QZ, XM, and DS exhibited the highest genetic diversity, while NA and ND had the lowest genetic diversity. Genetic differentiation among all populations, except $\mathrm{HN}$, was low compared to the genetic differentiation between $\mathrm{HN}$ and the other 11 putative populations. These 12 putative populations were divided into two subgroups. One group consisted of XM, DS, and QZ. The other group consisted of the other eight putative populations with
\end{abstract}

Genetics and Molecular Research 16 (1): gmr16019068 
the exception of HN. The HN Island population requires further study due to its large genetic distance from the other 11 putative populations. Problems with the current conservation strategy are pointed out and suggestions given based on genetic information.

Key words: Fenneropenaeus penicillatus; Microsatellite; Genetic diversity; Genetic differentiation; Conservation strategy

\section{INTRODUCTION}

Fenneropenaeus penicillatus (Alcock, 1905, common name: redtail prawn or redtail shrimp), also known as Penaeus penicillatus (Alcock, 1905), is one of the most commercially important shrimps for both harvest and aquaculture. It is mainly distributed in the Indo-West Pacific and Indian oceans from the southern coast of China to Indonesia, Thailand, India, and Pakistan (Neal and Maris, 1985; Lavery et al., 2004). It was once a target capture species in the 20th century. The wild catch reached its peak in the 1980s in China and then decreased rapidly afterward, mainly because of the overexploitation of wild populations and/or the pollution of the estuarine environment. With the development of aquaculture techniques, $F$. penicillatus aquaculture boomed along the south coast of China until the outbreak of largescale shrimp diseases in the late 1980s (Wu et al., 1996; Chen et al., 1997). F. penicillatus is now considered a suitable candidate for aquaculture along the south coast in winter and the east coast in summer because of its high tolerance to temperature and salinity variance ( $\mathrm{Hu}$ et al., 1987). In 2005, it was included in China's Red List of Endangered Species because of the rapid decline of wild populations.

Genetic variation, which can be affected by the effective population size, mutation, genetic drift, and selection, is among the three major components of biodiversity that the World Conservation Union (IUCN) has recommended for conservation (McNeely et al., 1990). In addition, ongoing evolutionary processes as well as historical factors affect genetic variation among populations within species (Mitchell-Olds et al., 2007; Sloan et al., 2008). Population genetic data is needed to inform conservation management (Neel and Ellstrand, 2003), which is the key to recovering the natural resources of $F$. penicillatus.

Various molecular markers, such as restriction fragment length polymorphisms (RFLP), amplified fragment length polymorphisms (AFLP), simple sequence repeats (SSRs or microsatellite loci), and so on, are used to detect population genetic diversity and population differentiation (Marsan et al., 1998; Garcia-Mas et al., 2000; Fasoli et al., 2016; Kaur et al., 2016; Ferreira et al., 2016). SSRs are evolutionarily neutral and have high numbers of polymorphisms, wide genomic distribution, co-dominant segregation patterns, and a high degree of reproducibility (Kijas et al., 1995). SSRs have been widely used in evaluating the genetic diversity and differentiation of different wild populations of shrimps, including Litopenaeus setiferus (Ball and Chapman, 2003), Penaeus monodon (Supungul et al., 2000), and Litopenaeus vannamei (Valles-Jimenez et al., 2004).

Despite the economic and ecological importance of F. penicillatus, knowledge of its genetic diversity and structure throughout its wide distribution range is limited (Zhang et al., 2012; Cao et al., 2012). To our knowledge, this study is the first to apply the SSR technique to studying the genetic diversity and differentiation of $F$. penicillatus along the southern coast of China. In this study, we used 10 SSR markers to investigate the genetic diversity and

Genetics and Molecular Research 16 (1): gmr16019068 
population structure of $F$. penicillatus from 12 locations to understand the level of genetic variation and differentiation within and among populations of this species along the southeast coast of China. Suggestions for conservation strategies are also given based on the genetic information obtained.

\section{MATERIAL AND METHODS}

\section{Sampled populations}

Wild samples of $F$. penicillatus from 12 locations distributed along the southeast coast of China were collected. These 12 locations included Beihai (BH), Dongshan (DS), Hainan (HN), Lianjiang (LJ), Nanao (NA), Ningde (ND), Putian (PT), Quanzhou (QZ), Xiamen (XM), Shenzheng (SZ), Zhanjiang (ZJ), and Zhangpu (ZP). All samples were fresh and mature when collected between 2006 and 2011. They were kept on ice and then transferred to a $-20^{\circ} \mathrm{C}$ freezer until needed. A total of 30 samples from each location were analyzed. The location and time of collection are shown in Table 1 and Figure 1.

Table 1. Sampling site, sample size, and sampling date of Fenneropenaeus penicillatus putative populations.

\begin{tabular}{l|c|c|c|l}
\hline Population & Abbreviation & Sample size & Latitude/Longitude & Date \\
\hline Beihai & BH & 30 & $21^{\circ} 21^{\prime} 00^{\prime \prime} \mathrm{N}, 109^{\circ} 07^{\prime} 18^{\prime \prime} \mathrm{E}$ & October 15,2011 \\
\hline Dongshan & DS & 30 & $23^{\circ} 44^{\prime} 06^{\prime \prime} \mathrm{N}, 117^{\circ} 16^{\prime} 44^{\prime \prime} \mathrm{E}$ & May 6,2007 \\
\hline Hainan & HN & 30 & $18^{\circ} 59^{\prime} 03^{\prime \prime} \mathrm{N}, 110^{\circ} 50^{\prime} 27^{\prime \prime} \mathrm{E}$ & December 13,2011 \\
\hline Lianjiang & LJ & 30 & $26^{\circ} 10^{\prime} 39^{\prime \prime} \mathrm{N}, 119^{\circ} 37^{\prime} 18^{\prime \prime} \mathrm{E}$ & September 8,2007 \\
\hline Nanao & NA & 30 & $23^{\circ} 24^{\prime} 00^{\prime \prime} \mathrm{N}, 117^{\circ} 01^{\prime} 34^{\prime \prime} \mathrm{E}$ & May 25,2007 \\
\hline Ningde & ND & 30 & $26^{\circ} 38^{\prime} 15^{\prime \prime} \mathrm{N}, 119^{\circ} 35^{\prime} 49^{\prime \prime} \mathrm{E}$ & October 20,2007 \\
\hline Putian & PT & 30 & $25^{\circ} 24^{\prime} 30^{\prime \prime} \mathrm{N}, 119^{\circ} 06^{\prime} 49^{\prime \prime} \mathrm{E}$ & November 20,2006 \\
\hline Quanzhou & QZ & 30 & $24^{\circ} 50^{\prime} 47^{\prime \prime} \mathrm{N}, 118^{\circ} 37^{\prime} 09^{\prime \prime} \mathrm{E}$ & November 15,2007 \\
\hline Xiamen & XM & 30 & $24^{\circ} 24^{\prime} 07^{\prime \prime} \mathrm{N}, 118^{\circ} 08^{\prime} 49^{\prime \prime} \mathrm{E}$ & October 29,2007 \\
\hline Shenzheng & SZ & 30 & $22^{\circ} 27^{\prime} 05^{\prime \prime} \mathrm{N}, 114^{\circ} 13^{\prime} 49^{\prime \prime} \mathrm{E}$ & September 8,2007 \\
\hline Zhanjiang & ZJ & 30 & $21^{\circ} 05^{\prime} 50^{\prime \prime} \mathrm{N}, 110^{\circ} 44^{\prime} 31^{\prime \prime} \mathrm{E}$ & October 12,2011 \\
\hline Zhangpu & ZP & 30 & $24^{\circ} 00^{\prime} 22^{\prime \prime} \mathrm{N}, 117^{\circ} 43^{\prime} 06^{\prime \prime} \mathrm{E}$ & September 28,2007 \\
\hline
\end{tabular}

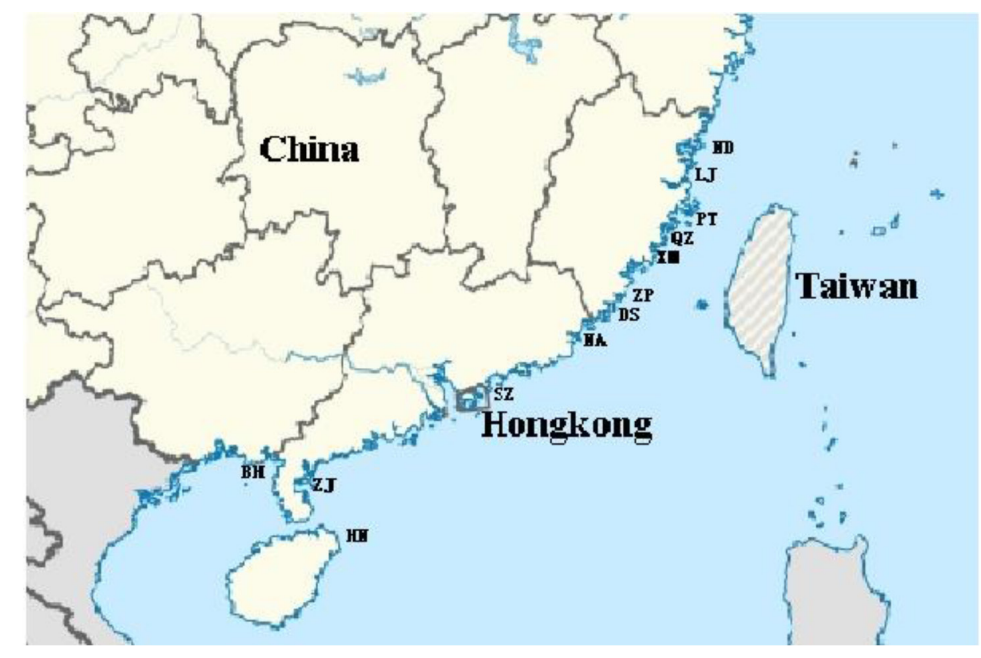

Figure 1. Sampling sites of 12 Fenneropenaeus penicillatus putative populations.

Genetics and Molecular Research 16 (1): gmr16019068 


\section{SSR analysis}

Genomic DNA was extracted using Gene DNA Extraction Kit SK 1252 (Sangon Biotech [Shanghai] Co., Ltd., Shanghai) according to the manufacturer instructions. Ten previously developed microsatellite primers were used (Cao et al., 2012). The optimal reaction conditions for SSR amplification were as follows: $1 \mathrm{X}$ Taq polymerase buffer, 20.0 $\mathrm{mM} \mathrm{MgCl}, 0.25 \mathrm{U}$ Taq DNA polymerase (Promega Inc., USA), 10 ng template DNA, 4 mmol forward primer, $4 \mathrm{mmol}$ reverse primer, and $2 \mathrm{mM}$ dNTPs in a $10 \mathrm{ml}$ total reaction volume. The amplification reaction for each primer was performed with an initial 5 min denaturation at $94^{\circ} \mathrm{C}$, followed by 32 cycles of $30 \mathrm{~s}$ at $94^{\circ} \mathrm{C}, 30 \mathrm{~s}$ at annealing temperature $\left(\mathrm{Ta}{ }^{\circ} \mathrm{C}\right)(\mathrm{CaO}$ et al., 2012), $1 \mathrm{~min}$ at $72^{\circ} \mathrm{C}$, and a $5 \mathrm{~min}$ final extension at $72^{\circ} \mathrm{C}$. The PCR products were electrophoresed on Sequi-Gen sequencing cells and then stained by the non-radioactive silver method. Fragment size was visually determined by comparison to the ladder.

\section{Data analysis}

Mean number of alleles per locus $(A)$, mean effective number of alleles per locus $\left(A_{e}\right)$, polymorphism information content (PIC), observed heterozygosity $\left(H_{\mathrm{O}}\right)$, and expected heterozygosity $\left(H_{\mathrm{E}}\right)$ were used to estimate genetic diversity using POPGENE32 (Yeh et al., 1999). Departures from Hardy-Weinberg equilibrium (HWE) were tested, and a global test of heterozygote deficit across populations was conducted by GENEPOP (Rousset, 2008) based on the Markov chain method with 1000 dememorization steps, 100 batches, and 1000 iterations per batch. Sequential Bonferroni correction (Rice, 1989) was applied for the significance of multiple tests. Allele identity was used to calculate the inbreeding coefficient $\left(F_{\text {IS }}\right)$ in each population in GENEPOP. Deficit or excess of heterozygotes $(D)$ was calculated as $\left(H_{\mathrm{O}}-H_{\mathrm{E}}\right) /\left(H_{\mathrm{E}}\right)$.

Genetic distance $(D)$ and gene flow $\left(N_{\mathrm{m}}\right)$ were also calculated using POPGENE32. Coefficient of gene differentiation $\left(F_{\mathrm{ST}}\right)$ was measured using FSTAT (Goudet, 1995). Unweighted pair group method with arithmetic mean (UPGMA) cluster analysis was performed to demonstrate the relationships using Nei's genetic distance in MEGA 4.0 (Tamura et al., 2007). Isolation by distance was tested using IBD (Isolation by Distance) (Jensen et al., 2005).

STRUCTURE 2.3.4 (Pritchard et al., 2000) was used to demonstrate the population structure using admixture mode and correlated allele frequencies. Length of burn-in period and number of Markov chain Monte Carlo (MCMC) reps after burn-in were both set to 100,000. The number of independent runs of $\mathrm{K}$ was set as 1-20. The number of iterations was 10 . Results from STRUCTURE were inputted into Structure Harvester (Earl and VonHoldt, 2012) for the most probable number of subpopulations based on the K method (Evanno et al., 2005). The bar plot graph with the best $\mathrm{K}$ fit was generated by STRUCTURE.

\section{RESULTS}

\section{Genetic diversity}

The average polymorphism information content (PIC) was 0.4208 and ranged from 0.3093 to 0.5154 . Mean number of alleles per locus $(A)$ and mean effective number of alleles per locus $\left(A_{e}\right)$ ranged from 2.9000 to 3.9000 and 1.6913 to 2.2915 , respectively, with averages of 3.3916 and 1.9326 . The observed heterozygosity $\left(H_{\mathrm{O}}\right)$ and expected heterozygosity $\left(H_{\mathrm{E}}\right)$

Genetics and Molecular Research 16 (1): gmr16019068 
were 0.2503 and 0.3849 , ranging from 0.2028 to 0.3092 and 0.2746 to 0.5216 , respectively. Quanzhou, Xiamen, and Dongshan showed the highest genetic diversity. Among the 10 microsatellite markers used, four uncovered low levels of polymorphisms (less than 4; FP-18, FP-83, and FP-11), while others had a high number of alleles $(\geq 4)$ and some had very high allele numbers ( $\geq 7$; FP-53, FP-46, FP-45, and FP-10).

A total of 41 out of 120 possible tests significantly deviated from HWE after sequential Bonferroni correction due to heterozygote deficiency as indicated by $F_{\text {IS }}$ and deficit or excess of heterozygotes (D) (Table 2).

Table 2. Genetic diversity statistics of Fenneropenaeus penicillatus Alcock populations.

\begin{tabular}{l|c|c|c|c|c|c|c|c}
\hline Population & Abbr. & PIC & $A$ & $A_{e}$ & $H_{\mathrm{O}}$ & $H_{\mathrm{E}}$ & $\mathrm{D}$ & $F_{\mathrm{IS}}$ \\
\hline Beihai & BH & 0.412 & 3.1 & 1.857 & 0.264 & 0.325 & -0.186 & 0.137 \\
\hline Dongshan & DS & 0.515 & 3.5 & 2.048 & 0.239 & 0.491 & -0.513 & 0.511 \\
\hline Hannan & HN & 0.495 & 3.3 & 2.283 & 0.309 & 0.489 & -0.367 & 0.364 \\
\hline Lianjiang & LJ & 0.398 & 2.9 & 1.716 & 0.243 & 0.286 & -0.152 & 0.160 \\
\hline Nanao & NA & 0.311 & 3.2 & 1.757 & 0.203 & 0.275 & -0.261 & 0.257 \\
\hline Ningde & ND & 0.309 & 3 & 1.691 & 0.243 & 0.290 & -0.162 & 0.160 \\
\hline Putian & PT & 0.456 & 3.3 & 2.038 & 0.261 & 0.417 & -0.374 & 0.368 \\
\hline Quanzhou & QZ & 0.505 & 3.5 & 2.292 & 0.273 & 0.522 & -0.476 & 0.480 \\
\hline Xiamen & XM & 0.484 & 3.8 & 2.096 & 0.258 & 0.455 & -0.433 & 0.422 \\
\hline Shenzhen & SZ & 0.361 & 3.5 & 1.694 & 0.241 & 0.314 & -0.233 & 0.239 \\
\hline Zhanjiang & ZJ & 0.391 & 3.9 & 1.829 & 0.234 & 0.385 & -0.391 & 0.410 \\
\hline Zhangpu & ZP & 0.412 & 3.7 & 1.892 & 0.235 & 0.370 & -0.365 & 0.389 \\
\hline Mean & & 0.421 & 3.392 & 1.933 & 0.250 & 0.385 & -0.350 & \\
\hline PIC p & & & & & & & \\
\hline
\end{tabular}

$\mathrm{PIC}=$ polymorphism information content; $A=$ mean number of alleles per locus; $A_{\rho}=$ mean effective number of alleles per locus; $H_{\mathrm{O}}=$ observed heterozygosity; $H_{\mathrm{E}}=$ expected heterozygosity; $D=$ deficit or excess of heterozygous; $F_{\text {IS }}=$ inbreeding coefficient.

\section{Genetic differentiation}

The genetic distance (D) among 12 wild F. penicillatus putative populations ranged from 0.0127 to 0.3676 (Table 3). The coefficients of gene differentiation between pairs of putative populations are shown in Table 4 . The coefficient of gene differentiation in all putative populations $\left(F_{\mathrm{ST}}\right)$ was 0.1155 and the gene flow in all putative populations $\left(N_{\mathrm{m}}\right)$ was 1.9152 . The genetic differentiation was the highest between $\mathrm{HN}$ and the other 11 locations, based on the genetic distance. This was consistent with results of UPGMA analysis, which showed HN separated from the other 11 putative populations (Figure 2). There was no correlation between the genetic and geographic distance of the 12 putative populations $(Z=4237.46, r=0.1621)$ based on IBD analysis.

Table 3. Genetic distances $(D)$ among Fenneropenaeus penicillatus Alcock from 12 locations.

\begin{tabular}{l|c|c|c|c|c|c|c|c|c|c|c|c}
\hline & BH & DS & HN & LJ & NA & ND & PT & QZ & XM & SZ & ZJ & ZP \\
\hline BH & $* * * *$ & & & & & & & & & & \\
\hline DS & 0.1193 & $* * * *$ & & & & & & & & & \\
\hline HN & 0.3676 & 0.1432 & $* * * *$ & & & & & & & & \\
\hline LJ & 0.0476 & 0.1245 & 0.3051 & $* * * *$ & & & & & & & \\
\hline NA & 0.0473 & 0.1253 & 0.3145 & 0.0134 & $* * * *$ & & & & & & \\
\hline ND & 0.0589 & 0.1308 & 0.3032 & 0.0441 & 0.0233 & $* * * *$ & & & & & \\
\hline PT & 0.0454 & 0.0655 & 0.2151 & 0.0380 & 0.0352 & 0.0545 & $* * * *$ & & & & \\
\hline QZ & 0.1003 & 0.0673 & 0.1553 & 0.1064 & 0.0980 & 0.0717 & 0.0588 & $* * * *$ & & & & \\
\hline XM & 0.0753 & 0.0477 & 0.1743 & 0.0851 & 0.0733 & 0.0505 & 0.0464 & 0.0292 & $* * * *$ & & \\
\hline SZ & 0.0642 & 0.1234 & 0.3290 & 0.0292 & 0.0200 & 0.0279 & 0.0440 & 0.0977 & 0.0844 & $* * * *$ & & \\
\hline ZJ & 0.0479 & 0.0950 & 0.2341 & 0.0244 & 0.0303 & 0.0569 & 0.0357 & 0.0906 & 0.0789 & 0.0408 & $* * * *$ & \\
\hline ZP & 0.0418 & 0.0879 & 0.2602 & 0.0219 & 0.0127 & 0.0294 & 0.0192 & 0.0662 & 0.0437 & 0.0350 & 0.0344 & $* * * *$ \\
\hline
\end{tabular}

Genetics and Molecular Research 16 (1): gmr16019068 
Table 4. Coefficients of gene differentiation $\left(F_{\mathrm{ST}}\right)$ among Fenneropenaeus penicillatus Alcock from 12 locations.

\begin{tabular}{l|c|c|c|c|c|c|c|c|c|c|c|c}
\hline & BH & DS & HN & LJ & NA & ND & PT & QZ & XM & SZ & ZJ & ZP \\
\hline BH & $* * * *$ & & & & & & & & & & \\
\hline DS & 0.1287 & $* * * *$ & & & & & & & & & \\
\hline HN & $0.3094^{*}$ & 0.1003 & $* * * *$ & & & & & & & & \\
\hline LJ & $0.0786^{*}$ & 0.1475 & $0.2880^{*}$ & $* * * *$ & & & & & & \\
\hline NA & $0.0825^{*}$ & $0.1555^{*}$ & $0.3027^{*}$ & 0.0124 & $* * * *$ & & & & & & \\
\hline ND & $0.1004^{*}$ & 0.1558 & $0.2912^{*}$ & $0.0801^{*}$ & 0.0368 & $* * * *$ & & & & & & \\
\hline PT & 0.0512 & 0.0476 & $0.1744^{*}$ & 0.0499 & 0.0496 & 0.0765 & $* * * *$ & & & & \\
\hline QZ & $0.1068^{*}$ & 0.0336 & 0.1053 & 0.1273 & $0.1266^{*}$ & 0.0931 & $0.0403^{*}$ & $* * * *$ & & & & \\
\hline XM & 0.0866 & 0.0226 & 0.1348 & $0.1110^{*}$ & $0.1019^{*}$ & 0.0665 & 0.0313 & 0.0037 & $* * * *$ & & & \\
\hline SZ & $0.1008^{*}$ & 0.1380 & $0.2921^{*}$ & 0.0434 & 0.0258 & $0.0414^{*}$ & 0.0528 & $0.1101^{*}$ & 0.1016 & $* * * *$ & & \\
\hline ZJ & 0.0587 & 0.0858 & 0.2017 & 0.0271 & 0.0412 & $0.0832^{*}$ & 0.0267 & 0.0801 & 0.0753 & 0.0502 & $* * * *$ & \\
\hline ZP & $0.0505^{*}$ & 0.0829 & $0.2237^{*}$ & 0.0230 & 0.0077 & 0.0381 & 0.0048 & $0.0594 *$ & 0.0364 & 0.0419 & 0.0297 & $* * * *$ \\
\hline
\end{tabular}

*Adjusted $\mathrm{P}$ value after sequential Bonferroni correction was lower than 5\%.

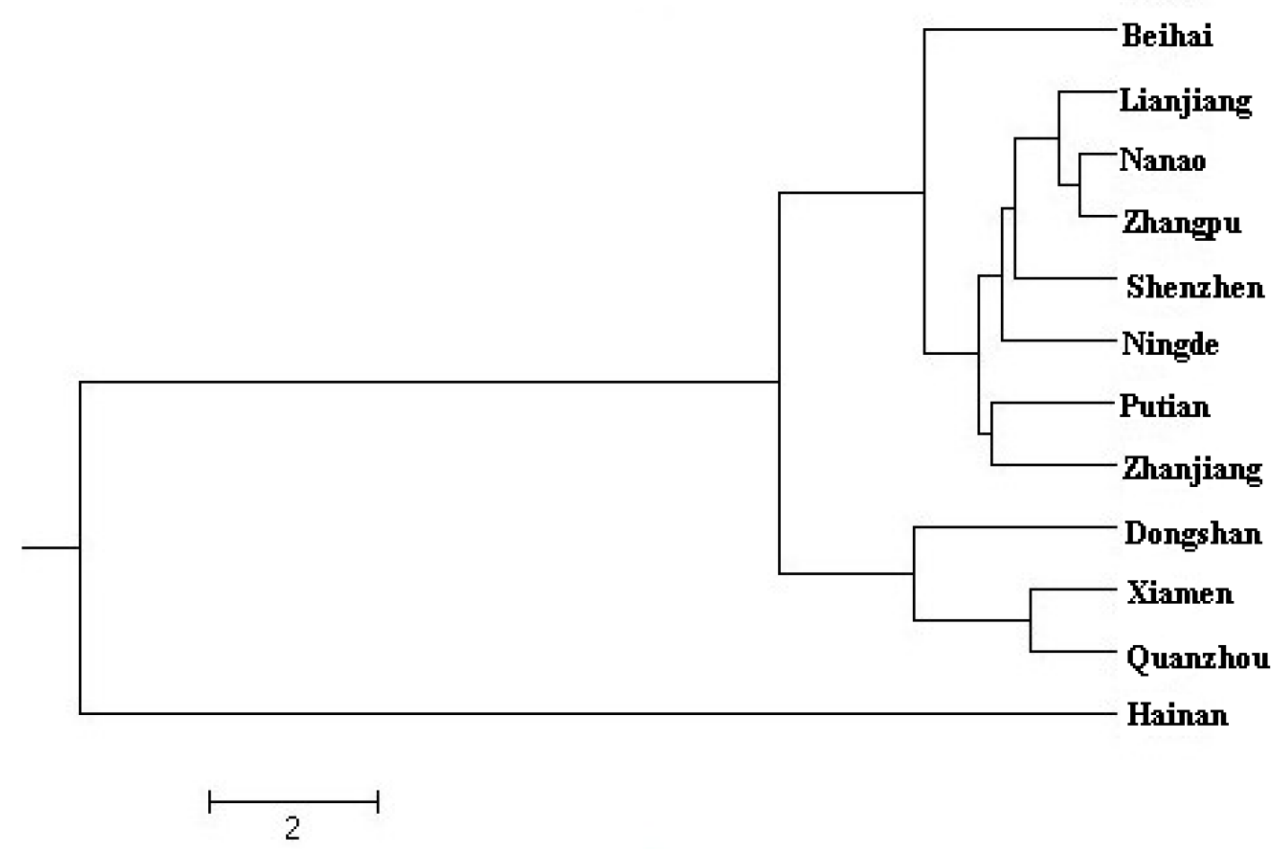

Figure 2. Unweighted pair group method with arithmetic mean (UPGMA) dendrogram for Fenneropenaeus penicillatus Alcock from 12 locations.

\section{Population structure}

STRUCTURE software was used to measure the population structure of $F$. penicillatus from 12 locations. $\mathrm{K}=2$ was chosen based on the highest delta $\mathrm{K}$ value. Individuals from 12 locations were clustered into two main groups (Figure 3). One population had some individuals from DS, HN, PT, QZ, XM, ZJ, and ZP. The other group included the rest of the individuals.

Genetics and Molecular Research 16 (1): gmr16019068 


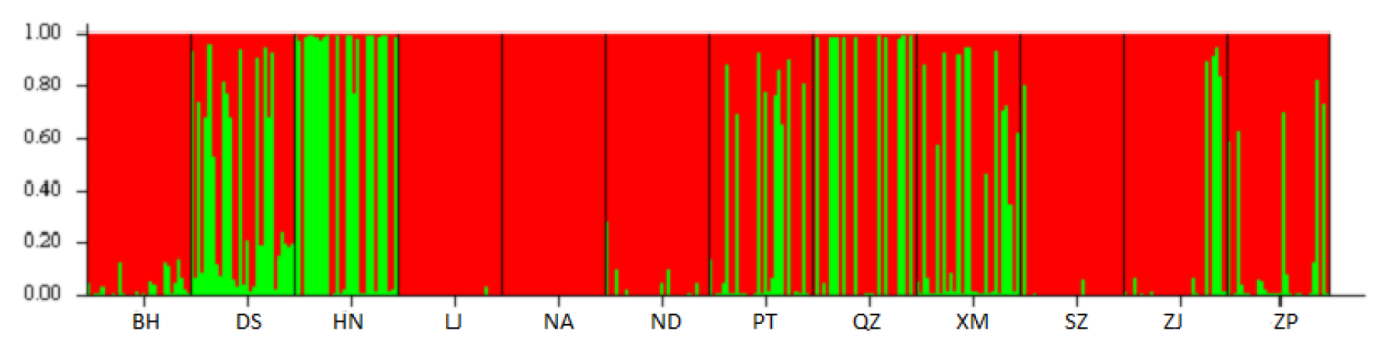

Figure 3. Population structure of Fenneropenaeus penicillatus Alcock from 12 locations by STRUCTURE.

\section{DISCUSSION}

\section{Genetic diversity}

Evaluating genetic diversity is an integral component of conservation and management plans concerning endangered species. Although microsatellite markers lack the potential ability to test the "direct effect" of genetic-fitness correlations and should preferably be carried out in a context-driven setting, they have shown weak yet positive and significant correlations between genetic diversity and fitness in a variety of species (Allentoft and O'Brien, 2010). We analyzed the genetic diversity of $F$. penicillatus populations using 10 microsatellite markers. The PIC values found in the present study $(0.309-0.515)$ are within the range of highly informative and medially informative markers according to Botstein et al. (1980), and can be used to identify the genetic diversity of the populations. Population diversity within exploited species can contribute to their long-term sustainability and should be incorporated more explicitly into management and conservation schemes (Hilborn et al., 2003; Hutchinson, 2008).

In general, the number of alleles detected in this study (3-8) was similar to that of Litopenaeus vannamei (2-12, Valles-Jimenez et al., 2005), but much lower than those reported for other shrimp species, such as Penaeus monodon (14 to 83, Supungul et al., 2000; Brooker et al., 2000) and L. setiferus (10 to 76, Ball and Chapman, 2003). The heterozygosity calculated for $F$. penicillatus populations in this study showed lower genetic variation than that found in L. vannamei (0.425-0.964) (Benzie, 2000) and P. monodon (0.47-1.0) (Xu et al., 2001). However, similar heterozygosity results were found for $L$. vannamei $(0.164-0.535)$ (Valles-Jimenez et al., 2005). In comparison with that of other shrimps, the genetic diversity of $F$. penicillatus is at the lower end. A loss of genetic diversity has been shown to lead to reduced fitness and adaptive potential to environmental challenges and diseases (Allentoft and O'Brien, 2010). Accordingly, populations lacking genetic diversity often exhibit an increased rate of extinction (Markert et al., 2010).

Genetic diversity was the highest in DS, followed by QZ, HN, and XM. This might be partly explained by several past conservation release events in the DS, XM, and QZ areas. Firstgeneration shrimps cultured from wild, disease-free shrimps with no genetic modifications were released into the coastal environment in DS, XM, and QZ in order to increase the population size. The lowest genetic diversity was found in the NA and ND populations. Inbreeding, genetic drift, restricted gene flow, and small population size all contribute to a

Genetics and Molecular Research 16 (1): gmr16019068 
reduction in genetic diversity (Furlan et al., 2012). Small population size might be the most likely culprit since a recent rapid decline in wild population sizes has been reported as a result of overexploitation of wild shrimp populations and environmental changes (e.g., marine and estuarine pollution). In addition, habitat fragmentation may increase the role of random genetic drift to the extent that genetic diversity in neutral marker genes is reduced (Johansson et al., 2007). NA and ND are surrounded by small island(s) that may function as possible marine barrier(s). The low genetic diversity in the NA and ND populations merits special attention from conservation geneticists and governments for further studies and protection.

\section{Genetic differentiation and population structure}

Lacking physical barriers to migration (Bohonak, 1999) as well as a mode of development, planktonic dispersal and adult migration (Hughes et al., 2004) are thought to account for the level of gene flow and genetic differentiation in marine species. Alternatively, oceanographic current patterns, local hydrographic events, and geographic features may contribute to population structure.

The $F_{\mathrm{ST}}$ value in our study, mostly because of the high $F_{\mathrm{ST}}$ between the HN population and other 11 populations, was much higher than that of $F$. chinensis $(0.01045-0.03569$, Meng et al., 2009), but lower than that of Penaeus merguiensis between the Gulf of Thailand and Andaman Sea $\left(F_{\mathrm{ST}}=0.203\right.$, Wanna et al., 2004) and also within Gulf of Thailand populations $\left(F_{\mathrm{ST}}=0.173\right.$, Wanna et al., 2004). The genetic distance was within the range of 0.15 among the 11 populations, which was a little lower than that observed for $F$. chinensis $(0.1442-0.2523$, Meng et al., 2009). The level of genetic differentiation of $F$. penicillatus is related to its seasonal life cycle pattern, which consists of a near-shore planktonic larval stage, estuarine postlarval to juvenile stages, and a return to the marine environment as mature spawn in the winter. Its dispersal capacity throughout its geographic range primarily depends on the planktonic larval stage, which is affected by oceanographic currents, the spawning migration ability of mature spawn, and the location of the fishing and nursery grounds. The current along the southeast coast of China experiences seasonal changes. In the spring, when F. penicillatus is in the spawning and near-shore planktonic larval stages, it is dominated by the southwestward longshore current (Zhu et al., 2013). In the summer and fall, when F. penicillatus is more estuarine, it is controlled more by the northeastward Kuroshio Current (Zhu et al., 2013). The longshore current, in particular, aids in the dispersal of $F$. penicillatus during the planktonic larval stage, which causes certain levels of mixture of $F$. penicillatus. In addition, DS is a major aquaculture site for $F$. penicillatus. Parents with high tolerance to diseases and a high growth rate are chosen from different populations/geographic regions for use in aquaculture. Escapes from aquaculture cause a mixture of wild and cultured populations and thus a mixture of different geographic putative populations. Current conservation strategies that involve the release of individuals from other locations in the local area also enhance the mixture of putative populations.

However, the genetic distance between $\mathrm{HN}$ and the other 11 populations was high. The measure of genetic distance between populations also agrees with the UPGMA result where the 11 populations clustered first and then clustered with the HN population. The HN population comes from HN Island, which is located along the south coast of China. The physical barrier of the island may prohibit the gene flow of $\mathrm{HN}$ with the other 11 populations. Despite the high genetic distance between HN and the other 11 populations and the UPGMA

Genetics and Molecular Research 16 (1): gmr16019068 
results, STRUCTURE clustered 12 putative populations into two major populations. Most individuals from $\mathrm{HN}$ and some individuals from DS, XM, QZ, PT, ZJ, and ZP were clustered in group 1, while the rest of the individuals were clustered into the other group. Individuals were mixed in population 1 (HN, DS, XM, QZ, PT, ZJ, and ZP). Possible reasons could include the aquaculture industry in DS and/or the conservation events in the XM, DS, and $\mathrm{QZ}$ areas. Individuals from $\mathrm{HN}$ were brought to the DS aquaculture station and escapes from aquaculture mixed with local DS populations and/or individuals from $\mathrm{HN}$ were used as parents to generate F1 offspring for later release into local areas.

\section{Hardy-Weinberg equilibrium and heterozygote deficit}

Hardy-Weinberg global tests across populations showed that all 12 populations significantly deviated from HWE after Bonferroni correction. Deviation from Hardy-Weinberg proportions indicates selection, inbreeding, or the presence of population substructure in the case of deficiency of heterozygotes. The disequilibrium is attributable to a heterozygosity deficit as indicated by positive $F_{\text {IS }}$ values. Positive $F_{\text {IS }}$ values were detected in all 12 populations, ranging from 0.137 to 0.511 ; these values were lower than those of wild $L$. vannamei populations from Panama to Mexico (0.53; Valles-Jimenez et al., 2005), but much higher than those of wild P. monodon populations (0.082; Xu et al., 2001). According to Prout and Barker (1993), null alleles, assortative mating (not reported for $F$. penicillatus), inbreeding from sib mating, and the temporal Wahlund effect account for positive $F_{\text {IS }}$.

The Wahlund effect is one of the possible causes of deviation from HWE and positive $F_{\text {IS }}$ in this study. Based on the STRUCTURE results, two populations were found among the 12 locations. Locations HN, DS, XM, QZ, PT, ZJ, and ZP showed a mixture of individuals, and possibly a mixture of population structures, which led to the high possible $F_{\text {IS }}$ in these groups. The deviation from HWE and positive $F_{\text {IS }}$ observed in our study could also possibly be a result of the small population size and high level of selection pressure, which were consistent with

the fact that $F$. penicillatus is now considered an endangered species due to its declining wild population size and changing environmental conditions (estuarine and near-shore pollution).

Shrimp conservation strategies are very different from typical plant or animal conservation strategies because we have less control of their wild environment and lack the ability to track individuals. The current conservation strategy for F. penicillatus in China is based on the Provisions on the Propagation and Release of Aquatic Organisms. The main strategy is releasing F1 offspring of local wild F. penicillatus populations into the marine environment. However, this conservation strategy is problematic.

Based on the current conservation strategy, local parents are primarily chosen based on disease-free local species without genetic modifications. However, there are many reports of released individuals from other geographic regions (populations). This results from the lack of a clear definition of 'local species' and a lack of understanding of the F. penicillatus population structure. Using different populations in the release process causes admixture of populations and further deviation from Hardy-Weinberg Equilibrium. This was confirmed by both the genetic diversity and genetic differentiation results.

It was suggested by Hilborn et al. (2003) that application of different release times, different geographic regions, and different life history strategies would greatly benefit biocomplexity. With respect to life history, releasing individuals with the same life history will cause more competition than releasing individuals with different life histories. In addition, the

Genetics and Molecular Research 16 (1): gmr16019068 
release site should be chosen carefully with regard to the ecosystem.

Multiple conservation strategies should be used instead of a single conservation strategy. It has been shown that a single strategy of deliberate overharvesting for maximum catch causes a loss of biocomplexity (Council, 1996). Based on current information, it appears that most of the released individuals come from DS, which has many aquaculture farms that generate F1 offspring. Using the same population excludes alternate strategies that may have done well under current environmental conditions while increasing the success rate if conditions change (Hilborn et al., 2003). Conservation strategies for $F$. penicillatus should be divided into two parts based on its life history. Both the marine environment and the freshwater environment should receive attention in its conservation plan.

The capability of marine species for long-distance dispersal makes it hard to devise proper conservation strategies. Genetic methods are important, but they alone are not capable of resolving key management problems (e.g., how many stocks are there?) because the high level of migration eliminates some of the genetic evidence of population structures. More large- and fine-scale information, in addition to genetic information, should be gathered in order to create an effective conservation strategy.

\section{Conflicts of interest}

The authors declare no conflict of interest.

\section{ACKNOWLEDGMENTS}

Research supported by the National Natural Science Foundation of China (\#31272668) and the Foundation for Innovative Research Team of Jimei University, China (\#2010A004).

\section{REFERENCES}

Allentoft ME and O’Brien J (2010). Global amphibian declines, loss of genetic diversity and fitness: a review. Diversity 2: 47-71.

Ball AO and Chapman RW (2003). Population genetic analysis of white shrimp, Litopenaeus setiferus, using microsatellite genetic markers. Mol. Ecol. 12: 2319-2330. http://dx.doi.org/10.1046/j.1365-294X.2003.01922.x

Benzie JAH (2000). Population genetic structure in penaeid prawns. Aquacult. Res. 30: 95-119. http://dx.doi.org/10.1046/ j.1365-2109.2000.00412.x

Bohonak AJ(1999). Dispersal, gene flow, and population structure. Q. Rev. Biol. 74:21-45.http://dx.doi.org/10.1086/392950

Botstein D, White RL, Skolnick M and Davis RW (1980). Construction of a genetic linkage map in man using restriction fragment length polymorphisms. Am. J. Hum. Genet. 32: 314-331.

Brooker AL, Benzie JAH, Blair D and Versini JJ (2000). Population structure of the giant tiger prawn Penaeus monodon in Australian waters, determined using microsatellite markers. Mar. Biol. 136: 149-157. http://dx.doi.org/10.1007/ $\underline{\mathrm{S} 002270050017}$

Cao YY, Li ZB, Zhang GL, Chen XJ, et al. (2012). Isolation and characterization of ten microsatellite markers of Fenneropenaeus penicillatus. Conserv. Genet. Resour. 4: 261-263. http://dx.doi.org/10.1007/s12686-011-9520-6

Chen SL, Chen QX, Hu TH, Lei G, et al. (1997). Purification and properties of acid phosphatase from Penaeus penicillatus (Alcock). J. Xiamen Univ. (Natur. Sci.) 36: 121-125.

Council ENP (1996). Egypt Demographic and Health Survey 1995. Preliminary report. Cairo Egypt National Population Council Mar. 41:67-72.

Earl DA and VonHoldt BM (2012). STRUCTURE HARVESTER: a website and program for visualizing STRUCTURE output and implementing the Evanno method. Conserv. Genet. Resour. 4: 359-361. http://dx.doi.org/10.1007/ s12686-011-9548-7

Evanno G, Regnaut S and Goudet J (2005). Detecting the number of clusters of individuals using the software

Genetics and Molecular Research 16 (1): gmr16019068 
STRUCTURE: a simulation study. Mol. Ecol. 14: 2611-2620. http://dx.doi.org/10.1111/j.1365-294X.2005.02553.x

Fasoli G, Barrio E, Tofalo R, Suzzi G, et al. (2016). Multilocus analysis reveals large genetic diversity in Kluyveromyces marxianus strains isolated from Parmigiano Reggiano and Pecorino di Farindola cheeses. Int. J. Food Microbiol. 233: 1-10. http://dx.doi.org/10.1016/j.ijfoodmicro.2016.05.028

Ferreira JR, Pereira JF, Turchetto C, Minella E, et al. (2016). Assessment of genetic diversity in Brazilian barley using SSR markers. Genet. Mol. Biol. 39: 86-96. http://dx.doi.org/10.1590/1678-4685-GMB-2015-0148

Furlan E, Stoklosa J, Griffiths J, Gust N, et al. (2012). Small population size and extremely low levels of genetic diversity in island populations of the platypus, Ornithorhynchus anatinus. Ecol. Evol. 2: 844-857. http://dx.doi.org/10.1002/ ece3.195

Garcia-Mas J, Oliver M, Gomez-Paniagua H and De Vicente MC (2000). Comparing AFLP, RAPD and RFLP markers for measuring genetic diversity in melon. Theor. Appl. Genet. 101: 860-864. http://dx.doi.org/10.1007/s001220051553

Goudet J (1995). Fstat version 1.2: a computer program to calculate Fstatistics. J. Hered. 86: 485-486.

Hilborn R, Quinn TP, Schindler DE and Rogers DE (2003). Biocomplexity and fisheries sustainability. Proc. Natl. Acad. Sci. USA 100: 6564-6568. http://dx.doi.org/10.1073/pnas.1037274100

Hu QB, Qiu JW, Hong JM and Yu DG (1987). The study of aquaculture techniques of Penaeus in two seasons. Journal of Xiamen Fisheries College 9: 1-7.

Hughes D, Coulson G and Warren I (2004). A Framework for Developing Reflective and Dynamic P2P Networks (RaDP2P). International Conference on Peer-To-Peer Computing, Proceedings, IEEE Xplore, 282-283.

Hutchinson WF (2008). The dangers of ignoring stock complexity in fishery management: the case of the North Sea cod. Biol. Lett. 4: 693-695. http://dx.doi.org/10.1098/rsbl.2008.0443

Jensen JL, Bohonak AJ and Kelley ST (2005). Isolation by distance, web service. BMC Genet. 6: 13. http://dx.doi. org/10.1186/1471-2156-6-13

Johansson M, Primmer CR and Merilä J (2007). Does habitat fragmentation reduce fitness and adaptability? A case study of the common frog (Rana temporaria). Mol. Ecol. 16: 2693-2700. http://dx.doi.org/10.1111/j.1365294X.2007.03357.X

Kaur K, Sharma V, Singh V, Wani MS, et al. (2016). Development of novel SSR markers for evaluation of genetic diversity and population structure in Tribulus terrestris. 3 Biotech. 6: 1-10.

Kijas JM, Fowler JC and Thomas MR (1995). An evaluation of sequence tagged microsatellite site markers for genetic analysis within Citrus and related species. Genome 38: 349-355. http://dx.doi.org/10.1139/g95-045

Lavery S, Chan TY, Tam YK and Chu KH (2004). Phylogenetic relationships and evolutionary history of the shrimp genus Penaeus s.l. derived from mitochondrial DNA. Mol. Phylogenet. Evol. 31: 39-49. http://dx.doi.org/10.1016/j. ympev.2003.07.015

Markert JA, Champlin DM, Gutjahr-Gobell R, Grear JS, et al. (2010). Population genetic diversity and fitness in multiple environments. BMC Evol. Biol. 10: 205. http://dx.doi.org/10.1186/1471-2148-10-205

Marsan PA, Castiglioni P, Fusari F, Kuiper M, et al. (1998). Genetic diversity and its relationship to hybrid performance in maize as revealed by RFLP and AFLP markers. Theor. Appl. Genet. 96: 219-227. http://dx.doi.org/10.1007/ $\underline{\mathrm{s} 001220050730}$

McNeely JA, Miller KR, Reid WV, Mittermeier RA, et al. (1990).Conserving the World's Biological Diversity. IUCN, World Resources Institute, Conservation International, WWF-US and the World Bank: Washington, DC.

Meng XH, Wang QY, Jang IK, Liu P, et al. (2009). Genetic differentiation in seven geographic populations of the fleshy shrimp Penaeus (Fenneropenaeus) chinensis based on microsatellite DNA. Aquaculture 287: 46-51. http://dx.doi. org/10.1016/j.aquaculture.2008.10.030

Mitchell-Olds T, Willis JH and Goldstein DB (2007). Which evolutionary processes influence natural genetic variation for phenotypic traits? Nat. Rev. Genet. 8: 845-856. http://dx.doi.org/10.1038/nrg2207

Neal RA and Maris RC (1985). Fisheries biology of shrimp and shrimp-like animals. In The Biology of Crustacea (10). Economic Aspects: Fisheries and Culture (A.J. Provenzano Jr., ed., D.E. Bliss, Series ed.), 1-100, Academic Press, London.

Neel MC and Ellstrand NC (2003). Conservation of genetic diversity in the endangered plant Eriogonum ovalifolium var. vineum (Polygonaceae). Conserv. Genet. 4: 337-352. http://dx.doi.org/10.1023/A:1024017029933

Pritchard JK, Stephens M and Donnelly P (2000). Inference of population structure using multilocus genotype data. Genetics 155: 945-959.

Prout T and Barker JS (1993). F statistics in Drosophila buzzatii: selection, population size and inbreeding. Genetics 134: 369-375.

Rice WR (1989). Analyzing tables of statistical tests. Evolution 43: 223-225.

Rousset F (2008). genepop'007: a complete re-implementation of the genepop software for Windows and Linux. Mol.

Genetics and Molecular Research 16 (1): gmr16019068 
Ecol. Resour. 8: 103-106. http://dx.doi.org/10.1111/j.1471-8286.2007.01931.x

Sloan DB, Barr CM, Olson MS, Keller SR, et al. (2008). Evolutionary rate variation at multiple levels of biological organization in plant mitochondrial DNA. Mol. Biol. Evol. 25: 243-246. http://dx.doi.org/10.1093/molbev/msm266

Supungul P, Sootanan P, Klinbunga S, Kamonrat W, et al. (2000). Microsatellite polymorphism and the population structure of the black tiger shrimp (Penaeus monodon) in Thailand. Mar. Biotechnol. (NY) 2: 339-347.

Tamura K, Dudley J, Nei M and Kumar S (2007). MEGA4: Molecular Evolutionary Genetics Analysis (MEGA) software version 4.0. Mol. Biol. Evol. 24: 1596-1599. http://dx.doi.org/10.1093/molbev/msm092

Valles-Jimenez R, Cruz P and Perez-Enriquez R (2005). Population genetic structure of Pacific white shrimp (Litopenaeus vannamei) from Mexico to Panama: Microsatellite DNA variation. Mar. Biotechnol. 6: 475-484.

Wanna W, Rolland JL, Bonhomme F and Phongdara A (2004). Population genetic structure of Penaeus merguiensis in Thailand based on nuclear DNA variation. J. Exp. Mar. Biol. Ecol. 311: 63-78. http://dx.doi.org/10.1016/j. jembe.2004.04.018

Wu YL, Wang FG, Chen QZ and Hong J (1996). The study of baculovirus in Fenneropenaeus penicillatus. Acta Oceanol. Sin. 18: 93-96.

Xu Z, Primavera JH, de la Pena LD, Pettit P, et al. (2001). Genetic diversity of wild and cultured Black Tiger Shrimp (Penaeus monodon) in the Philippines using microsatellites. Aquaculture 199: 13-40. http://dx.doi.org/10.1016/ $\underline{\text { S0044-8486(00)00535-4 }}$

Yeh FC, Boyle T and Yang RC (1999). POPGENE: Microsoft Window-based Freeware for Population Genetic Analysis, version 1.31. University of Alberta: Edmonton, Canada.

Zhang GL, Cao YY, Li ZB, Chen J, et al. (2012). Analysis of the genetic diversity and differentiation of Fenneropenaeus penicillatus populations using AFLP technology. Chin. J. Oceanology Limnol. 30: 440-445. http://dx.doi.org/10.1007/ s00343-012-1125-8

Zhu DY, Li L and Guo XG (2013). Seasonal and interannual variations of surface current in the southern Taiwan Strait to the west of Taiwan Shoals. Chin. Sci. Bull. 58: 4171-4178. http://dx.doi.org/10.1007/s11434-013-5907-y

Genetics and Molecular Research 16 (1): gmr16019068 